Man and Nature

L'homme et la nature

\title{
Women, Allegory and the French Revolution: The Case of Armed Liberty
}

\section{Vivian Cameron}

Volume 4, 1985

URI : https://id.erudit.org/iderudit/1011838ar

DOI : https://doi.org/10.7202/1011838ar

Aller au sommaire du numéro

Éditeur(s)

Canadian Society for Eighteenth-Century Studies / Société canadienne d'étude du dix-huitième siècle

ISSN

0824-3298 (imprimé)

1927-8810 (numérique)

Découvrir la revue

Citer cet article

Cameron, V. (1985). Women, Allegory and the French Revolution: The Case of Armed Liberty. Man and Nature / L'homme et la nature, 4, 95-108.

https://doi.org/10.7202/1011838ar

Copyright (C Canadian Society for Eighteenth-Century Studies / Sociéte canadienne d'étude du dix-huitième siècle, 1985
Ce document est protégé par la loi sur le droit d'auteur. L'utilisation des services d'Érudit (y compris la reproduction) est assujettie à sa politique d'utilisation que vous pouvez consulter en ligne.

https://apropos.erudit.org/fr/usagers/politique-dutilisation/ 


\section{Women, Allegory and the French Revolution: The Case of Armed Liberty}

The image of armed liberty was extremely popular during the French Revolution. It appeared not only in high art, that is, works of the Salon ${ }^{1}$, but also in a wide range of popular materials, including broadsides, medals, patriotic ornaments, letterheads, temporary monuments in festivals, and the like. In this paper, I shall explore the reasons for this popularity, how the image was interpreted or read, and why it eventually disappeared.

The most significant use of armed liberty was on a chariot (Plate 1) which was paraded through the streets of Paris during the Festival of Liberty, celebrated on April 15, 1792. The vehicle supported an enormous eighteen (or twenty-four) foot, bronze-coloured plaster statue of Liberty. The festival itself, organized by Jacques-Louis David, the celebrated artist, honoured a group of Swiss soldiers who had mutinied against their aristocratic officers in Châteauvieux; were then suppressed; tried; in some cases broken on the wheel or sent to the galleys; then, as the country became more anti-royalist, were granted amnesty and finally honoured for their rebellion against their royalist officers. The chariot with the statue of Liberty came at the end of the procession. According to several newspaper descriptions, Liberty was seated, holding a bonnet of Liberty in one hand, a club in the other, and stepping on a broken yoke. The journalist of the Révolutions de Paris stressed the presence of the club: 


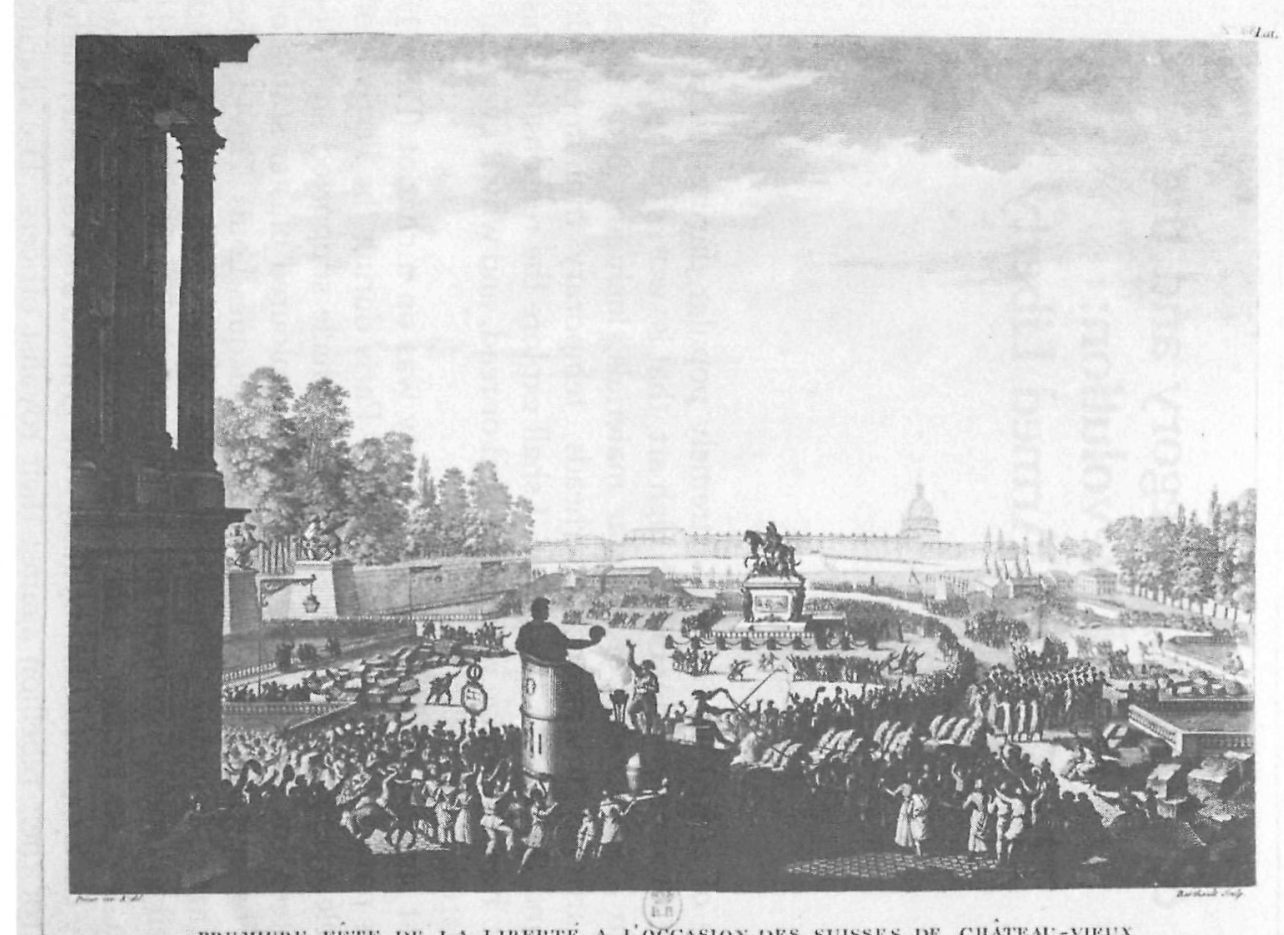

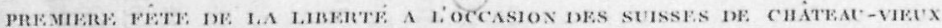
le is Avilal nos

1. Pierre Gabriel Berthault after Jean-Louis Prieur, Première Fête de la Liberté à l'occasion des Suisses de Château-vieux le 15 avril 1792. Engraving. Paris, Bibliothèque Nationale (Photo: Author). 
La statue de la liberté assise, la main appuyée sur une massue, imprimait le respect, \& eût fait baisser les yeux à un roi, s'il s'en fût trouvé sur son passage. N'oublions pas de faire remarquer que le sceptre de la liberté est une massue. ${ }^{2}$

By stating that the statue of Liberty would make the King lower his eyes, the writers were suggesting that Liberty was above the king, an idea which the printmaker, Pierre-Gabriel Berthault, translated literally in his illustration (Plate 1), although he inaccurately depicted Liberty with the orb of the world rather than with a club.

The club itself is important. Elsewhere, I have traced how this weapon, along with the other attributes of Hercules, was once connected with the French kings, including Henri IV, Louis XIV, Louis XV, and Louis XVI, and during the Revolution was transferred to images of the people, as, for instance, in a medal celebrating the taking of the Bastille (Plate 2), where we see crossed clubs. ${ }^{3}$ Cast in lead or tin, the medal, which showed on its recto a scene of the assault itself, sold cheaply on the streets of Paris. The aggrandizement of the people was both mythical and literal as some of the actual assailants wore these medals to indicate that they were amongst the victors. The people, too, had the force - and virtue - of Hercules.

But during the early years of the Revolution, female figures such as $\mathrm{La}$ Nation and Liberty were also equipped with the club of Hercules. ${ }^{4}$ Both genders were armed with the attributes of the God. However, after the Festival of Liberty in April 1792, mentioned above, it was the female figure of Liberty who would carry the club of Hercules for over a year. ${ }^{5}$

Although the April 1792 pageant in which this statue figured was called the Festival of Liberty, the festival also celebrated unity. An inscription on the chariot's base read 'Français, soyez unis, vous serez toujours libres.' This unity, however, was that of only certain groups of French people. Honouring those Swiss soldiers who had rebelled against the aristocracy, this pageant was opposed by the royalists and the moderates, those who wanted a constitutional monarchy. The discord can be read in the description of the festival by Robespierre, who was one of its supporters:

Cette fête qu'on prépare peut être vraiment utile à la liberté, et devenir le triomphe du peuple longtemps outragé, parce qu'elle terrasse les oppresseurs de la vertu et fait luire le jour de la vérité sur les attentats des tyrans. ${ }^{6}$

Furthermore, the festival not only honoured those Swiss soldiers but was also seen as 'an expiatory ceremony for the massacre of the Champ de Mars', ${ }^{7}$ which had taken place more than six months earlier when 


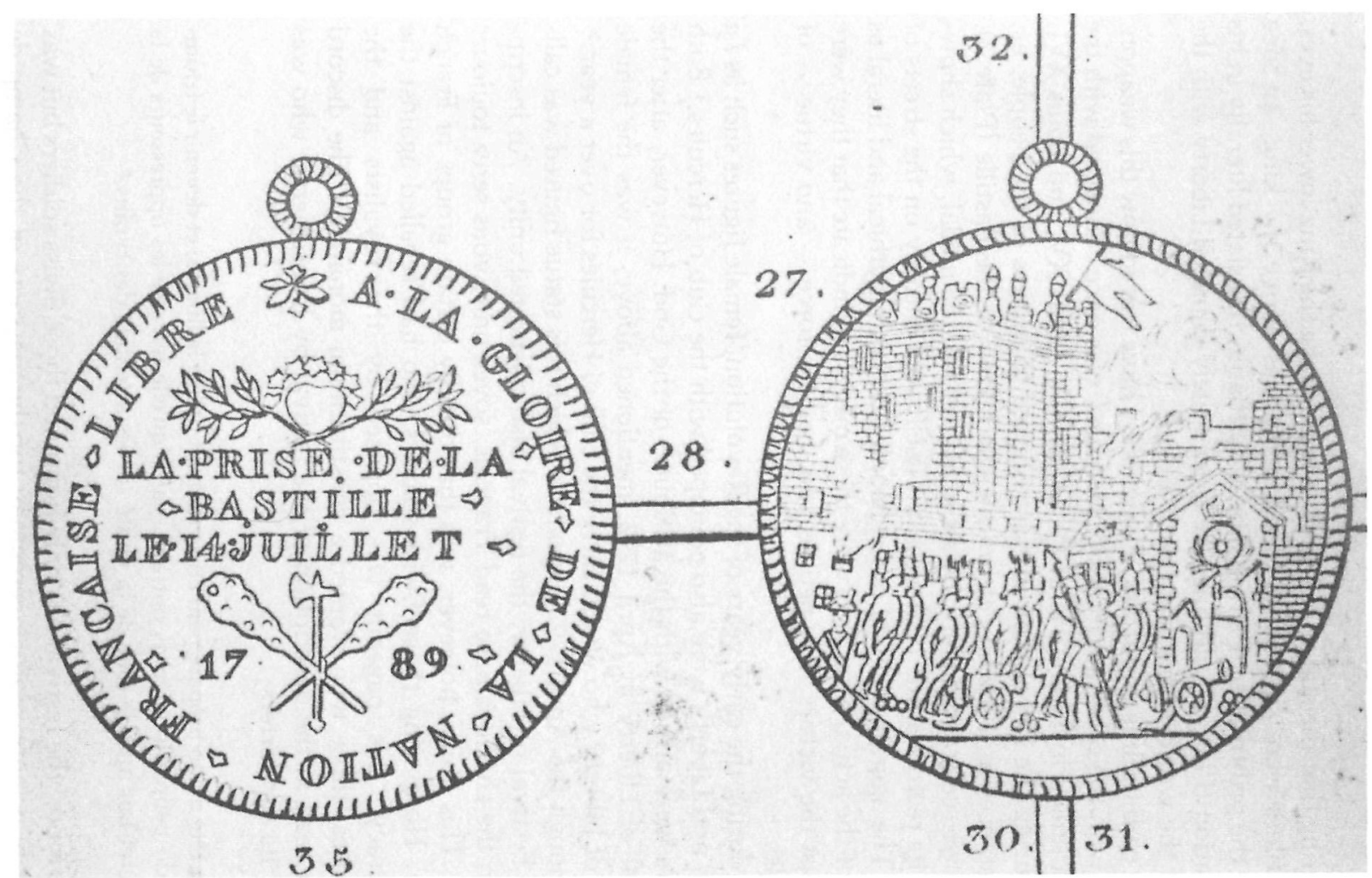

2. Medal, La Prise de la Bastille, 1789. (From Michel Hennin, Histoire numismatique de la Révolution Française, (Paris, 1826), II, plate 4 , no. 28.) 
municipal officers and National Guardsmen under Lafayette's command had fired on the people who called for a national referendum, asking for the King's abdication, after the royal family's flight to Varennes.

Allegorically, then, this liberty, won by force, represented only certain groups of people - the Girondin municipality, the Jacobins, the working people of Paris - and was clearly resisted by other French people, as discussions of the festival show. ${ }^{8}$ Representing the French people as a whole, as a unified body, was apparently impossible to the organizers.

Further interpretations should be added to the purely allegorical one, according to a document published in the following year. In an article in the November 13, 1793 issue of Révolutions de Paris, an anonymous writer addressed the question of how abstract concepts were interpreted:

C'est une chose qu'il ne faut pas se lasser de dire au peuple: la liberté, la raison, la vérité, ne sont que des êtres abstraits. Ce ne sont point là des dieux, car à proprement parler, ce sont des parties de nous-mêmes. La liberté n'est autre chose que notre volonté, qui a le pouvoir de se manifester \& de se réaliser .... C'est le rapport réel \& primitif des choses ....9

In this discourse, the author revealed that Liberty and other abstract conceptions were not abstract but parts of the viewer. Liberty was nothing but one's will, for instance, 'une partie de notre être.' What he appears to be saying is that these abstract personifications were to be read as parts of the whole, the whole being each French person, that is, as metonymns. If that is the case, this liberty as force could be read as the reader's will to be forceful.

To this metonymic reading could be added a literal one as well, and the anonymous author cited above discussed this also. Mentioning the example of Reason being represented by a woman in the Festival of Reason, he stressed that those who organize such a festival ought to offer to the people:

une femme dont la conduite rende (sic) la beauté respectable, dont la sévérité des moeurs \& des regards, dont la réputation sans tache, repousse la licence des désirs \& celle des propos; que celle qui est chargée d'un rôle si auguste ... imprime dans tous les coeurs par sa présence le respect qui leur est dû. ${ }^{10}$

This was not the first occasion during the Revolution when allegorical figures were read literally. An earlier discussion of 1790 centering on the four figures by Desjardins at the base of the statue of Louis XIV in the Place des Victoires also raised this issue. While the four figures represented enemies or countries which Louis XIV had conquered, the 
idea of exhibiting slaves with chains was now abhorrent to some. In a letter to a newspaper, one person wrote, 'Une nation libre ne saurait voir des chaînes à qui que ce soit, pas même à des êtres allégoriques. Nous enlèverons donc les esclaves aux statues de Henri IV et de Louis XIV.'11 When a group of artists tried to save the works and suggested exhibiting the statues without their chains, the motion was dismissed with the comment from deputy $M$. Bouche, ' ... on pouvait bien ôter aux quatre figures les attributs de l'esclavage, mais non pas le maintien de l'esclavage .... .'12

The armed figure of Liberty at the Festival of Liberty could then be interpreted in three different ways. On an allegorical level, she represented a certain group of people - the Girondin municipality, the Jacobins, the working people of Paris. On a metonymic level, this was their liberty that they had won by force. This liberty was a very part of them as free beings who defied those who had attempted to prohibit the festival. On a literal level, this armed liberty, I would speculate, could be identified with the militant women parading in the streets, with those who had petitioned for arms, who had paraded with arms, and who had protected the city of Paris in July 1789. What I am suggesting is that there was a connection made between the sculpture in this festival (and other images of armed Liberty) and actual women, those who marched on the Palace of the Tuileries that very day of the festival and attempted to menace the royal family, although to no avail. ${ }^{13}$

In this connection some comment should be made about the fact that the female figure of Liberty was not just female because of the Latin gender of the word. The French révolutionnaires could easily have chosen the male figure entitled 'the genius of liberty' which they selected for some coins. As Ian MacLean explains in his study of seventeenth century French women:

In the case of abstract virtues, the link with Latin gender is disregarded, and the female figure is taken to represent her sex as a whole, or an individual of her sex ... emblems ... being more commonly regarded as didactic at this time, offer more scope for writers hostile to women. (my italics) ${ }^{14}$

We can further speculate that the female figure expressed best the idea of liberty close to nature, close to instincts, away from the world of bon ton, since it was commonly felt that women were closer to organic nature, closer to a lack of inhibition, closer to the passions. With woman as metaphor for instinct, this could express the kind of reasoning of the people, called 'instinct,' for example, by Camille Desmoulins. ${ }^{15}$ 
The use of the female figure might also be considered an example of sexual inversion, defined as

... any act of expressive behavior which inverts, contradicts, abrogates, or in some fashion presents an alternative to commonly held cultural codes, values, and norms be they linguistic, literary or artistic, religious, or social and political. ${ }^{16}$

The historian Natalie Davis demonstrated in a study of such inversions in seventeenth-century France, that while anthropologists have assumed that sexual inversion is used as a source of 'order and stability' in an already ordered society, in France in the early modern period

The image of the disorderly woman ... was a multivalent image that could operate, first, to widen behavioral options for women within and even outside marriage, and second, to sanction riot and political disobedience for both men and women .... Play with the unruly woman is partly a chance for temporary release from the traditional and stable hierarchy, but it is also part of the conflict over efforts to change the basic distribution of power within society. ${ }^{17}$

On the one hand, the armed figure of Liberty at this festival seemed to encourage such 'political disobedience,' and at the same time, it was a sign of another dispute, that about the role of women in society, which was constantly being questioned during the Revolution, not only by the 'amazons,' but apparently in 1792 by some of the men as well. While there was a need to reaffirm continually the traditional domestic sphere which women were supposed to occupy, when the need arose they were given license to abandon that circle, to enter the pubic domain, and to assist men in their political struggles. In the months that followed the Festival of Liberty, women would participate in the invasion of the Tuileries on June 20,1792, and in the final seizure on August 10th; they would parade with arms at the Fête de la Fédération in 1792; they would act in food riots in 1793; they would form the political club entitled the Société des Citoyennes Républicaines Révolutionnaires in May 1793; they would participate in the expulsion of the Girondins from the Commune government and assist the Montagnards in their rise to power. If these activities by women were out of order, or disorderly, and if they ignored the conventional boundaries defined for women, the evidence shows that there was a political need for the 'unruly' woman during the years of 1792 and 1793. The plethora of images of armed Liberty appearing then symbolically represented this disorder and encouraged women to question the definition of traditional roles as well as that order itself. 
These images helped to give women the false assurance that the political groups they assisted would finally give them political legitimation, namely constitutional rights as citizens.

The power of the female armed Liberty was challenged at the Fête de la Réunion, celebrated on August 10,1793. Organized by the same artist who made the arrangements for the Festival of Liberty, Jacques-Louis David, the festival was also called the Fête de l'Unité et l'Indivisibilité, those concepts being visually propagandized in the pageant. Unity was immediately expressed when the deputies of the National Convention drank the waters from the statue of La Nature (Plate 3, top left) and proclaimed, 'Nous sommes tous ses enfants.' For men what this represented symbolically was the combination of the natural with the social, a move prescribed by Rousseau; for women it was a reminder of their natural duties, their maternal duties, reiterated throughout this festival. (At station two of the festival, for instance (Plate 3 , top centre), the heroines of the 1789 march to Versailles were honoured but were also admonished to be good mothers.) The indivisibility of the title of the pageant was now depicted by one figure, the amalgamation of social and natural man, the French people as Hercules (Plate 3, bottom left); it was he who would subsequently appear in other prints, coins, drawings, projects for sculpture and the like. The President of the National Convention explained at that festival of August 10, 1793, what the sculpture represented:

Peuple français, te voilà offert à tes propres regards sous un emblème fécond en leçons instructives. Ce géant dont la main puissante réunit \& rattache, en un seul faisceau, les départements qui font sa grandeur \& sa force, c'est toi. Ce monstre dont la main criminelle veut briser le faisceau, \& séparer ce que la nature a uni, c'est le Fédéralisme. Peuple dévoué à la haine \& à la conjuration de tous les despotes, conserve toute ta grandeur pour défendre ta liberté .... Fais à ceux qui veulent te diviser la même guerre quà ceux qui veulent t'anéantir; car ils sont également coupables. ${ }^{18}$

The opposition here is between those united by and in Nature and those outside of Nature, the latter including those who wanted to divide the people as well as those who wanted to destroy them - the Girondins as well as the Royalists. Those 'outside of Nature' were those who continued to perpetuate the practices of the ancien régime society with its many masks and disguises, easy to represent as an unnatural monster with a 'dragon de mer' head. While their language was one of artifice, that of bon ton, those who accepted Nature - represented as a colossal male human being - used a simple, unambiguous language and the familiar 


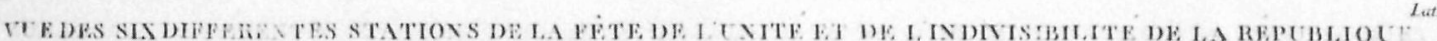
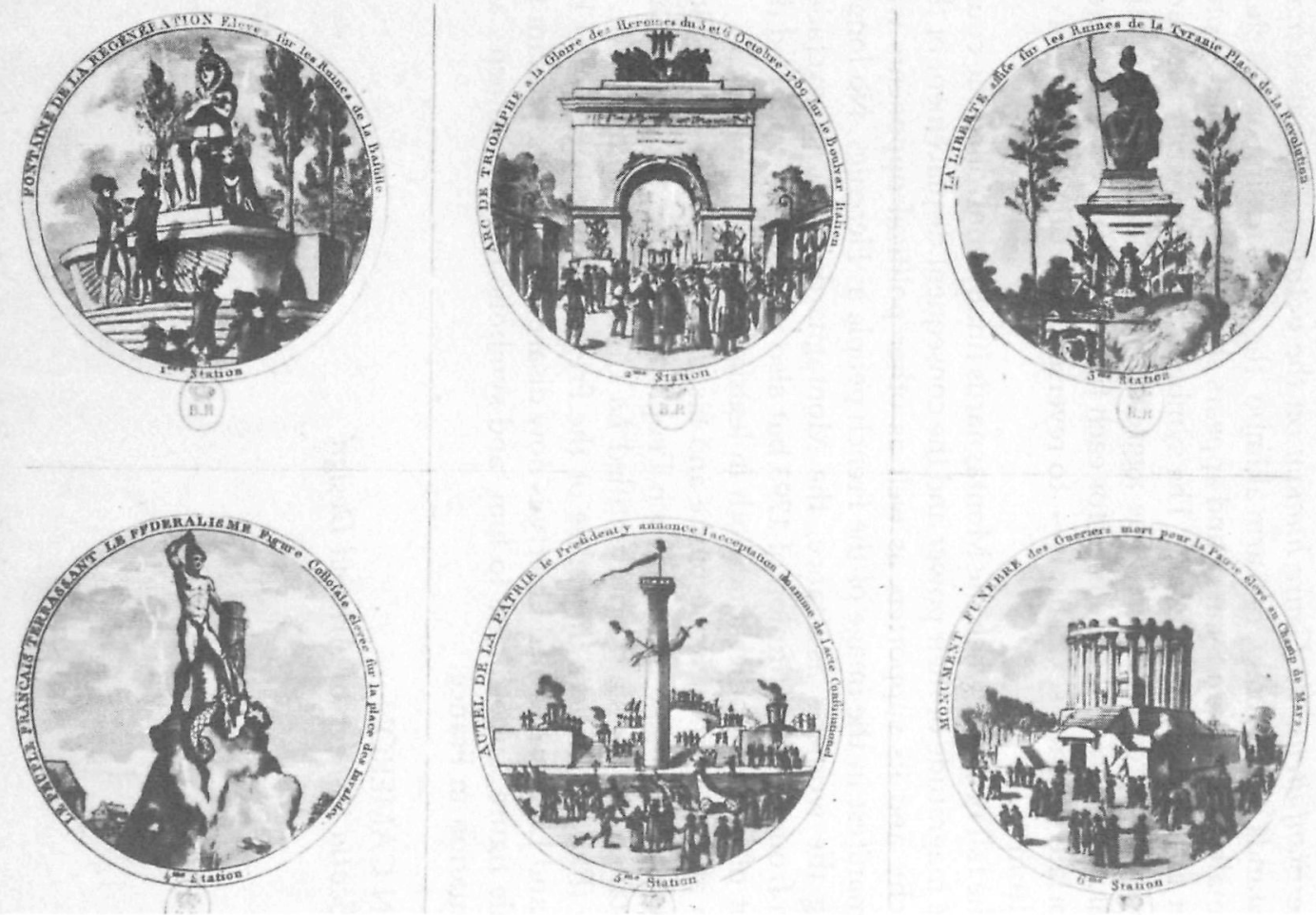

3. Anonymous, Vue des Six Différentes Stations de la Fête de l'Unité et de l'Indivisibilité de la République, c. 1793. Etching. Paris, Bibliothèque Nationale. (Photo: Author). 
form of address. Amongst those outside of Nature was the armed woman, who did not accept the maternal role prescribed for her by Rousseau. Between her and the colossal male figure was an implicit battle over the attributes of Hercules which represented the French people.

This male-female opposition is further suggested in a print (plate 4) by François-Marie Queverdo which honours Le Peuple Français on the top and the Bienfaiteurs du Genre humain on the bottom. The naked male figure stands aggressively, one arm akimbo, the other resting on his club. The female sways in an S-curve and appears shy, her head turned in profile, her eyes looking downward. The symbolic battle between male and female is more resolved here. The aggressiveness and the shyness, the gestural and emotional code used for each figure, is that now considered appropriate for each sex. This is - to reverse Davis' title - 'Woman on the Bottom'.

By the fall of 1793, when the Montagnards finally controlled the country, the magnitude of their power and the consequent displacement of the monarchy and its supporters as well as other political opponents was made manifest in the image of the French people as Hercules. No longer needing the women's assistance, the Montagnards not only excluded women from the Constitution of 1793 but also vigorously supported the concept of happy motherhood both in legislation and in imagery.

Even after the fall of Robespierre and his close supporters, this policy continued. The image of the French People as Hercules triumphed, as, for instance, in J. Allais' print entitled La Convention soutenue par le Peuple (Plate 5), where the figure of the French People is crowned by Union and Liberty. Armed Liberty is now disarmed, a mere attendant to the male figure, subordinate to him, and symbolic now of women's actual situation in France.

VIVIAN CAMERON

Nova Scotia College of Art and Design 


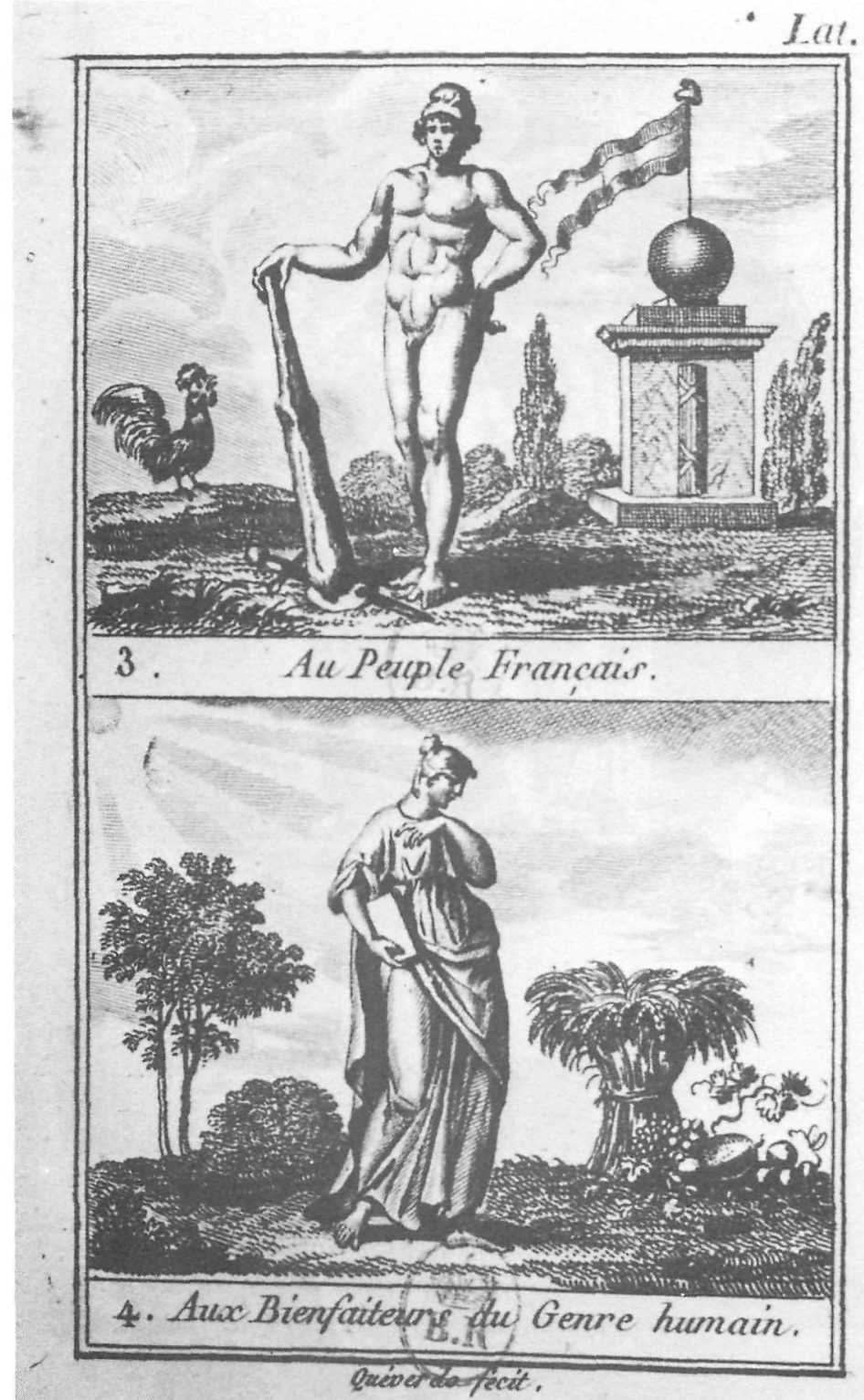

4. François-Marie Queverdo, Au Peuple Français and Aux Bienfaiteurs du Genre humain, c. 1793-94. Engraving. Paris, Bibliothèque Nationale. (Photo: Author). 


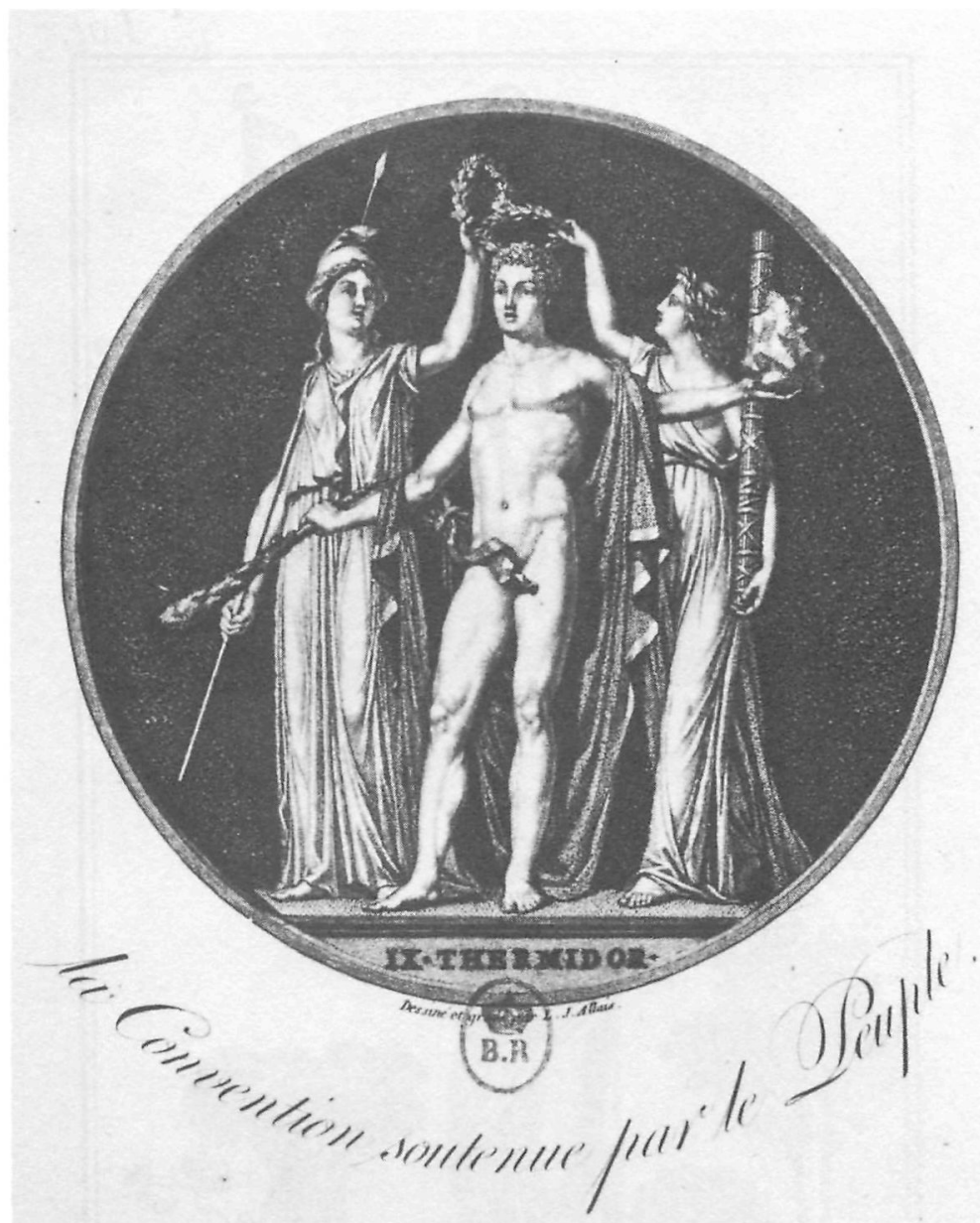

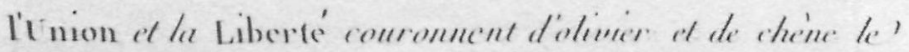
peuple Francais qui detroul une main armée de sel messue,

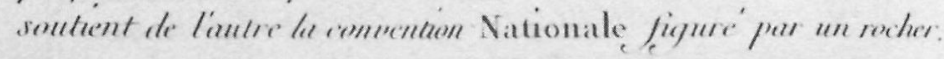

5. J. Allais, La Convention soutenue par le Peuple, c. 1794. Engraving. Paris, Bibliothèque Nationale. (Photo: Author). 


\section{Notes}

1 An example in high art is Nanine Vallain's Liberté discovered in the Club des Jacobins when it was closed late in 1794. See M. Furcy Raynaud, 'Les tableaux et objets d'art saisis chez les émigrés et condamnés et envoyés au Museum Central,' Nouvelles Archives de l'Art français, VI (1912), p. 24. For an illustration, see Maurice Agulhon, Marianne au Combat (Paris: Flammarion, 1979), first plate preceding introduction.

2 Révolutions de Paris, no. 145 (14-21 April 1792), pp. 101-102.

3 See the author's doctoral dissertation, 'Woman as Image and Image-Maker in Paris during the French Revolution,' Yale University 1983, pp. 249-343. On the medal, see Michel Hennin, Histoire numismatique de la Révolution française, 2 vols. (Paris, 1826), II, pl. 4, nos. 28, 29, 30, 31, for example. See also Aubin Louis Millin, Histoire métallique de la Révolution française (Paris, 1806), pl. III, nos. 11,12 and p. 7.

4 La Nation, pictured on one representation of the National Cocard, was depicted with the fasces wrapped around the club in Révolutions de Paris, no. 13 (3-10 October 1789), opp. p. 6. An early figure of Liberty as Hercules appeared on a medal produced for a contractor named Palloy, entrusted with the dismantling of the Bastille. The coin is published in Hennin, I, p. 62 and II, pl. 10, no. 74.

5 The gender of abstract personifications was not necessarily fixed. For instance, a female France, suggested for some coins, was replaced by a male 'génie de la France.' See Archives Parlementaires de 1787 à 1860, 82 vols. (Paris, 1862), XXIV, 9 April 1791, p. 679.

6 Account of the meeting on 6 April at the Jacobin Club in Philippe Joseph B. Buchez and Prosper Charles Roux, eds., Histoire Parlementaire de la Révolution Française, 40 vols. (Paris, 1834-38), XIV, p. 108.

7 Quoted in David Lloyd Dowd, Pageant-Master of the Republic: Jacques-Louis David and the French Revolution (Lincoln, Nebraska: University of Nebraska, 1948), p. 57.

8 See Buchez and Roux, XIV, pp. 78-123.

9 Révolutions de Paris, no. 215 (23 brumaire II or 13 November 1793), pp. 215-16.

10 Ibid.

11 Quoted from Richard Etlin, 'L'Architecture et la Fête de la Révolution,' in Les Fêtes de la Révolution, Colloque de Clermond-Ferrand (Juin 1974), ed. Jean Ehrard and Paul Viallaneix (Paris: Société des études robespierristes, 1977), p. 150. The issue is discussed on pp. 149-51.

12 Journal des Débats et des Décrets, 327 (28 June 1790), p. 2.

13 See Correspondance Secrète de l'Abbé de Salamon, chargé des affaires du SaintSiège pendant la Révolution avec le Cardinal de Zelada (1791-1792), ed. Vte. de Richemont (Paris, 1898), p. 504.

14 Ian MacLean, Woman Triumphant: Feminism in French Literature 1610-1652 (Oxford: Clarendon Press, 1977), p. 215. 
15 Jack Censer, Prelude to Power: The Parisian Radical Press 1789-1791 (Baltimore and London: The Johns Hopkins University Press, 1976), pp. 46-47 mentions and briefly discusses this. The association of nature, instinct and the people is made by Desmoulins in Révolutions de France et de Brabant, no. 9 (23 June 1790), pp. 397-98.

16 Barbara B. Babcock, 'Introduction,' The Reversible World, ed. Barbara B. Babcock (Ithaca, New York, and London: Cornell University Press, 1978), p. 14.

17 Nathalie Zemon Davis, 'Women on Top,' Society and Culture in Early Modern France (Stanford, California: Stanford University Press, 1975), p. 131.

18 Procès-verbal de la Convention nationale, XVIII (1-15 August 1793), p. 263. 